\title{
A Gyermeki Viselkedés Kérdőív legrövidebb változatának (CBQ VS) magyar adaptációja
}

\author{
D. MOLNÁR ÉVA ${ }^{1 *}$ - KOVÁCS DÉNES² \\ ${ }^{1}$ SZTE Neveléstudományi Intézet, Neveléselmélet Tanszék, Szeged \\ 2 SZTE ÁOK Gyermekgyógyászati Klinika és Gyermek Egészségügyi Központ, Szeged
}

(Beérkezett: 2018. szeptember 21.; elfogadva: 2019. január 14.)

\begin{abstract}
Elméleti háttér: A kisgyermekek körében végzett temperamentumkutatások egyik legismertebb és leggyakrabban használt mérőeszköze a 3-8 éveseknek szánt Gyermeki Viselkedés Kérdőív (Children's Behavior Questionnaire; CBQ), amely különböző változatokban is létezik, és amelynek magyar nyelvú változata ezidáig nem állt rendelkezésünkre. Cél: Tanulmányunk célja a CBQ legrövidebb változatának (CBQ VS) magyar adaptációja és a mérőeszköz pszichometriai mutatóinak ismertetése a hazai kutatók számára. Módszerek: Vizsgálatunkban 5-7 éves gyermekek $(n=201)$ és szüleik $(n=201)$ vettek részt három magyarországi településről. A kérdőívet a gyermekek szülei (176 anya és 25 apa) töltötték ki. A CBQ VS-H mellett vizsgáltuk a gyermekek végrehajtó funkcióit is a HTKS és DayNight tesztekkel. Eredmények: Az exploratív faktoranalízis eredményeként a magyar verzióban, hasonlóan az eredeti változathoz, három faktor különült el, amelyek jó belső megbízhatósági mutatókkal rendelkeztek: Erőfeszítés alapú kontroll (Cronbach-a: 0,76), Extraverzió (Cronbach-a: 0,78), Negatív érzelmi viszonyulás (Cronbach-a: 0,74). A temperamentum vizsgált dimenziói függetlennek bizonyultak a kitöltő személyétől (anya vagy apa), életkorától, családi állapotától és iskolai végzettségétól. Következtetések: Eredményeink alapján a Gyermeki Viselkedés Kérdőív legrövidebb változatának magyar verziója (CBQ VS-H) megbízhatóan múködik, és alkalmasnak tekinthetó a kisgyermekek temperamentumának és annak három dimenziójának vizsgálatára.
\end{abstract}

Kulcsszavak: temperamentum, gyermeki viselkedés, önszabályozás, CBQ, pszichometriai mutatók

\section{Bevezetés}

A Rothbart és munkatársai (Rothbart, Ahadi, \& Hershey, 1994; Rothbart, Ahadi, Hershey, \& Fisher, 2001) által kidolgozott, 3-8 évesek felmérésére szánt Gyermeki Viselkedés Kérdőív (Children's Behavior Questionnaire; CBQ) az egyik leggyakrabban használt kérdőív a temperamentumkutatá-

\footnotetext{
* Levelező szerző: Dr. D. Molnár Éva, SZTE Neveléstudományi Intézet, Neveléselmélet Tanszék, 6722 Szeged, Petófi S. Sgt. 30-34. E-mail: medu@edpsy.u-szeged.hu
} 
sokban. Több változata is készült az évek folyamán (Children's Behavior Questionnaire short; CBQ S; Children's Behavior Questionnaire very short; CBQ VS), és számos nyelvre is lefordították, azonban ezidáig magyar nyelvú változata nem született. A tanulmány célja ismertetni a kérdóív magyar nyelvre történő adaptálásának lépéseit, és a hazai kutatásokban való alkalmazásának lehetőségeit.

\subsection{Az eredeti kérdőív és az általa vizsgált terület bemutatása}

A kisgyermekek temperamentuma, a viselkedésben megnyilvánuló egyéni sajátosságok és különbségek vizsgálata régóta foglalkoztatja a kutatókat, az 1990-es évektől kezdődően intenzíven jelen van ez a terület a tudományos kutatásokban (l. Guthrie, Eisenberg, Fabes, Murphy, Holmgren, Mazsk és mtsai, 1997; Rothbart \& Bates, 2006). A nemzetközi terepen az egyik legismertebb mérőeszköznek számít a CBQ, amely 3-8 évesek temperamentumát vizsgálja szülői/gondozói vélekedések alapján. A mérőeszköz kidolgozása azon értelmezésen alapult, miszerint a temperamentum a reaktivitásban és önszabályozásban megnyilvánuló egyéni különbségek összessége, amit az öröklés és a tapasztalatok határoznak meg (Rothbart \& Derryberry, 1981). Eredeti változata (a CBQ Standard; Rothbart, Ahadi, \& Hershey, 1994; Rothbart, Ahadi, Hershey, \& Fisher, 2001) 195 itemet és 15 alskálát (skálánként 12-14 item) tartalmazott (Putnam \& Rothbart, 2006). A szülóknek 1-től (egyáltalán nem igaz az Ön gyermekére) 7-ig (teljes mértékben igaz az Ön gyermekére) terjedő skálán kellett megítélniük az adott tétel igazságtartalmát a gyermekükre vonatkoztatva. A skála mellett megjelent a „nem alkalmazható" kategória is, amit akkor választhattak a szülők, ha gyermeküket nem látták még az adott helyzetben viselkedni.

A CBQ egy temperamentumvizsgáló mérőeszközcsomag része, hiszen Rothbart és kutatócsoportja széles életkori skálára dolgozták ki a kérdőívüket azzal a céllal, hogy minden korosztályban lefedjék a fontosabb komponenseket. Kora gyermekkortól (Infant Behavior Questionnaire; Rothbart, 1981) az általános- és középiskolások számára készült változatokon keresztül (Early Childhood Behavior Questionnaire; ECBQ; Putnam, Gartstein, \& Rothbart, 2006; Temperament in Middle Childhood Questionnaire; TMCQ; Simonds \& Rothbart, 2004; Early Adolescent Temperament Questionnaire; EATQ; Capaldi \& Rothbart, 1992) egészen felnőttkorig (Physiological Reactions Questionnaire; Derryberry \& Rothbart, 1988) vizsgálják a temperamentum viselkedéses sajátosságait úgy, hogy az egyes itemeket az adott korosztályra jellemzők alapján dolgozzák ki. A CBQ eredeti változatával (Rothbart és mtsai, 1994; Rothbart és mtsai, 2001) számos vizsgálatot végeztek, aminek révén a temperamentumkutatások kiterjedhettek például a 
proszociális viselkedés, a problémás viselkedés, a negatív emóciókra adott szülői válaszok, és a stresszre adott fiziológiai válaszok közötti összefüggések feltárására is (Gilliam \& Shahar, 2006; Putnam \& Rothbart, 2006). Ezekból az összevetésekból kiderült, hogy a temperamentum viselkedéses megnyilvánulásainak vizsgálata helytálló, és a személyiség más területeivel öszszehasonlítva előrejelző, jósló szerepet tölt be.

Putnam és Rothbart (2006) a CBQ legrövidebb változatát azzal a szándékkal hozták létre, hogy külön mérőeszközben elérhetővé tegyék a temperamentum azon aspektusait azok számára, akik kifejezetten ezekre a területekre fókuszálnak. A CBQ-VS kidolgozásában figyelembe vették az első, több alskálából álló (CBQ Standard) mérőeszközben kapott faktoranalízis eredményét, és ennek következtében három faktort különítettek el, amelyek véleményük szerint a Big Five személyiségelmélet (Digman, 1990) három faktorának is megfeleltethetők (Putnam \& Rothbart, 2006). Az első faktor a Surgency, ${ }^{1}$ amely az Extraverzió megfelelóje lehet, és fóként az impulzivitás, magas élménykeresés és aktivitás pozitív megnyilvánulását, valamint a félénk skála negatív, alacsony megjelenését foglalja magában. A második faktor a Negatív érzelmi viszonyulás (Negative Affect), amely a Neuroticizmus személyiségfaktornak feleltethető meg, és amit a szomorúság, félelem, harag és diszkomfortérzés pozitív jelenléte, valamint a reaktivitáscsökkenés negatív megnyilvánulása jellemez. A harmadik faktor az Erőfeszítés alapú kontroll (Effortful Control), amely a Lelkiismeretesség személyiségdimenziónak feleltethető meg, és a gátlás, a figyelemfókusz, az alacsony élménykeresés és észlelési érzékenység pozitív megjelenését foglalja magában. A rövidítés következtében a CBQ VS mindhárom faktor esetében jó belső megbízhatósági (Cronbach- $\alpha$ ) mutatókkal rendelkezett (Surgency: 0,75, Negative Affect: 0,72, Effortful Control: 0,74; Putnam \& Rothbart, 2006).

\subsection{A mérőeszköz használatával nyert korábbi eredmények}

A CBQ legelső változatának (CBQ Standard; Rothbart és mtsai, 1994) megjelenésétól kezdődően számos átalakításon és fejlesztésen ment keresztül, továbbá több nyelvre ( $\mathrm{pl}$. francia, német, román, norvég, lengyel) is lefordították a két évtizedes múlttal rendelkező mérőeszköz eredeti és átdolgozott változatait egyaránt. ${ }^{2}$

\footnotetext{
1 Az eredeti kifejezést nehéz átültetni a magyar szaknyelvbe. Jelentését talán a legjobban az extraverzió fordítás ragadja meg, ugyanakkor nem teljesen azonos azzal, emiatt zárójelben az angol kifejezést is használjuk.

2 Letöltve: 2018. november 22-én: https:// research.bowdoin.edu/rothbart-temperamentquestionnaires/instrument-descriptions/the-childrens-behavior-questionnaire/
} 
A CBQ különböző változatait az önszabályozás vizsgálatában is gyakran használják, mivel egyik komponense az erőfeszítés alapú kontroll mérésére szolgál (Blair \& Razza, 2007). Az erőfeszítés alapú kontroll a temperamentum részének, az önszabályozás alapvető készségének tekinthető, ami Rothbart és Ahadi (1994) értelmezésében a domináns válasz gátlásának és a nem domináns válasz múködtetésének készsége. Leggyakrabban az iskolaérettséggel, az iskolai sikerességgel összefüggésben vizsgálják, és az eredmények kapcsán bizonyítottá vált alapvetó szerepe ebben a folyamatban (Blair, 2002; Blair \& Razza, 2007; Duncan és mtsai, 2007; Howse, Calkins, Anastopoulos, Keane, \& Shelton, 2003). Azok a gyerekek, akik képesek az erőfeszítés alapú kontrollra, magas önszabályozással rendelkeznek, jobb szociális kapcsolatokat alakítanak ki az iskolában (Eisenberg Valiente, Fabes, Smith, Reiser, \& Shepard, 2003; Valiente, Lemery-Chalfant, \& Castro, 2007), jobb matematikai és olvasási eredménnyel rendelkeznek, hatékonyabban szabályozzák negatív emócióikat (Raver, 2004), és összességében jobb tanulási, iskolai sikeresség jellemzi óket (Martin, Drew, Gaddis, \& Moseley, 1988; Normandeau \& Guay, 1998). Továbbá fontos tényezőnek számít az iskolai elköteleződésben és motivációban is, hiszen a magas erőfeszítés alapú kontrollal rendelkező gyerekek jobban elkötelezettek az iskolai feladatok iránt és magasabb tanulási motiváció jellemzi őket (Rothbart \& Jones, 1998).

Az utóbbi években több összehasonlító vizsgálatot is végeztek az erőfeszítés alapú kontroll és a végrehajtó funkciók múködése között, és bár mindkettót az önszabályozás alapvető készségének tekintik (Liew, 2012; Zhou, Chen, \& Main, 2012), a két komponens közötti kapcsolat ellentmondásos. Van egy-két folyamat, amely mindkét konstruktum meghatározásában lényeges (pl. gátlás, figyelem), de vannak olyan komponensek is, amelyek megnevezése, értelmezése eltérő (pl. munkamemória; D. Molnár, 2017). A két konstruktum közötti kapcsolat kimutatására eddig viszonylag kevés empirikus kutatás áll rendelkezésünkre, és ezekból az derült ki, hogy mérsékelt erősségú összefüggés mutatható ki az erőfeszítés alapú kontroll és a végrehajtó funkciók között (Carlson \& Moses, 2001; Davis, Bruce, \& Gunnar, 2002; Rothbart, Ellis, Rueda, \& Posner, 2003), ami elsősorban a két komponens különállóságát bizonyítja az önszabályozáson belül.

\subsection{A jelen vizsgálat célja}

A CBQ használatával az óvodáskorú gyermekek temperamentumáról, viselkedéses megnyilvánulásáról számos nemzetközi vizsgálati adat született. Tudomásunk szerint a kérdőívnek még nincs hazai adaptációja, így fontosnak tartottuk magyar nyelvre lefordítani, és az első vizsgálat eredményeiről, a méróeszköz pszichometriai mutatóiról beszámolni. Ez képezi a jelen tanulmány célkitûzését. 


\section{Módszer}

\subsection{Minta és eljárás}

A keresztmetszeti vizsgálatra 2016 tavaszán került sor, kényelmi mintavétellel, három magyarországi településen. A szülőket és gyerekeket az óvónókön keresztül értük el, és tájékoztattuk óket a vizsgálatban való részvétel anonimitásáról és a részvétel önkéntességéről. A vizsgálatban való részvételt szülői beleegyezéssel, a szülők aláírásával valósítottuk meg. A vizsgálatban 5-7 éves gyermekek ( $n=201$; 111 lány és 90 fiú) és szüleik $(n=201$; 176 anya és 25 apa) vettek részt. A minta szociodemográfiai jellemzőit az 1. táblázatban mutatjuk be. A gyermekek közül 51 ötéves, 71 hatéves és 66 hétéves volt a vizsgálat idején (13 gyereknek hiányzott a születési dátuma). Minden gyermek és szülő magyar anyanyelvú volt. A kérdőívet a gyermekek szülei töltötték ki, otthoni környezetben. A gyerekek felmérését az óvónők és az első szerző végezte az óvodákban, egyéni feladathelyzetben. Egy-egy vizsgálat 8-10 percet vett igénybe. A kutatást a Szegedi Tudományegyetem Neveléstudományi Doktori Iskolájának Etikai Bizottsága jóváhagyta.

1. táblázat. A szülői minta szociodemográfiai jellemzői

\begin{tabular}{|l|l|c|}
\hline \multicolumn{2}{|c|}{ Változó } & $\begin{array}{c}\text { Gyakoriság } \\
n(\%)\end{array}$ \\
\hline \multirow{5}{*}{ Életkor } & $\leq 23$ év & $3(1,5 \%)$ \\
\cline { 2 - 3 } & $24-29$ év között & $20(10,2 \%)$ \\
\cline { 2 - 3 } & $30-39$ év között & $136(69 \%)$ \\
\cline { 2 - 3 } & $40-49$ év között & $36(18,3 \%)$ \\
\cline { 2 - 3 } & $\geq 50$ év & $2(1 \%)$ \\
\hline Iskolai végzettség & legfeljebb nyolc általános iskolai osztály & $6(3 \%)$ \\
\cline { 2 - 3 } & szakmunkásképző/szakiskola & $43(21,8 \%)$ \\
\cline { 2 - 3 } & érettségi & $62(31,5 \%)$ \\
\cline { 2 - 3 } & föiskola & $62(31,5 \%)$ \\
\cline { 2 - 3 } & egyetem & $24(12,2 \%)$ \\
\hline Családi állapot & nótlen/hajadon & $9(4,6 \%)$ \\
\cline { 2 - 3 } & élettársi kapcsolat & $78(24,5 \%)$ \\
\cline { 2 - 3 } & házas & $0(0 \%)$ \\
\hline & elvált & $132 \%)$ \\
\hline & özvegy & \\
\hline
\end{tabular}




\subsection{A CBQ VS magyar nyelvre való adaptálásának menete}

A CBQ VS kérdőív magyar nyelvre történő adaptációja során kettős fordítást alkalmaztunk két független fordító bevonásával (az első fordító angol nyelvról magyarra, a második fordító magyar nyelvról angolra fordította). A végső változat létrehozásában figyelembe vettük mindhárom (eredeti angol, magyar, visszafordított angol) változatot, és a végleges szöveget a fordítók közremúködésével alakítottuk ki.

A válaszlehetőségeknél az eredeti hétfokú Likert-típusú skálát lecsökkentettük ötfokúra a magyar nyelv sajátosságai miatt (a hetes skála egyes megadott skálaértékei kapcsán - pl. alig, valamennyire - nehezen értelmezhető a különbség magyar nyelven). A két szélső és középső értéket megtartottuk, így az 1-es skálaértéknek meghagytuk az eredeti kifejezést (extremely untrue of your child - egyáltalán nem igaz az Ön gyermekére), valamint a 7-es skálaértéket 5-ösként szintén eredeti állapotában hagytuk (extremely true of your child - teljes mértékben igaz az Ön gyermekére). A középső, semleges skálaértéket (4 - neither true nor false of your child) 3 -as értékként jelenítettük meg (néha igaz rá, néha nem). Az eredeti 2-es és 3-as skálaértékhez tartozó értékelést (quite untrue, slightly untrue) összevontuk (2 - kevéssé igaz), és ugyanígy jártunk el az 5-ös és 6-os értékekkel is (slightly true, quite true), amit összevonva a 4-es értékkel jelöltünk (általában igaz). A skála mellett a „nem alkalmazható” kategóriát is feltüntettük, az eredeti kérdőívhez hasonlóan.

\subsection{Eszközök}

A vizsgálatban a CBQ VS-H mellett végrehajtó funkciókat vizsgáló mérőeszközöket is felvettünk, amit a gyerekekkel végeztünk el egyéni feladathelyzetben. Az egyik mérőeszköz a 20 itemes "Fej-Lábujjak-Térd-Vállak" („Head-Toes-Knees-Shoulders"; HTKS; Ponitz, McClelland, Matthews, \& Morrison, 2009; magyar nyelven: D. Molnár \& Kovács, 2018) volt, amelyben az utasításban elhangzottak helyett egy másik, előre megbeszélt tevékenységet kellett végrehajtaniuk a gyerekeknek (pl. „Érintsd meg a fejed” helyett meg kellett érinteniük a lábujjukat). A 16 itemes Nappal-Éjszaka Teszt (DayNight Test; Gerstadt, Hong, \& Diamond, 1994; magyar nyelven: D. Molnár \& Kovács, 2018) során az adatfelvevő egy Napot és egy Holdat jelképező képet mutatott az óvodásnak, akinek erre megadott kifejezésekkel (éjszaka, nappal - a képnek ellenkező jelentéssel) kellett válaszolnia. Mindkét mérőeszköz a munkamemóriát, a gátlást és a figyelem fókuszálását vizsgálja (Gerstadt és mtsai, 1994; Ponitz és mtsai, 2008; Ponitz és mtsai, 2009). Belső megbízhatóságuk a jelen vizsgálatban megfelelőnek bizonyult (HTKS: 
Cronbach- $\alpha=0,81$; Nappal-Éjszaka Teszt: Cronbach- $\alpha=0,94)$. Ezen kívül a szülők néhány demográfiai adatra (szülők neme, életkora, iskolai végzettsége, családi állapota) vonatkozó kérdést is megválaszoltak.

\subsection{Statisztikai elemzések}

Feltételeztük, hogy a Putnam és Rothbart (2006) által kialakított faktorstruktúra az általunk lefordított és használt kérdőívváltozatban is hasonló lesz, amit konfirmatív és exploratív faktorelemzéssel terveztünk bizonyítani. A CBQ VS-H faktorainak konvergens és divergens validitását egyéb változók (végrehajtó funkciókat vizsgáló HTKS és Nappal-Éjszaka Teszt) bevonásával ellenőriztük korrelációs elemzéssel. A kérdőívek belső megbízhatóságának becslésére Cronbach-alfa-mutatót számítottunk. A temperamentumjellemzők és a szociodemográfiai változók kapcsolatának vizsgálatára lineáris regresszió elemzést alkalmaztunk. Az elemzéseket az IBM-SPSS 24.0 és Mplus7 1.31 statisztikai programcsomagokkal végeztük.

\section{Eredmények}

\subsection{Faktorelemzés}

A CBQ VS-H tételeivel végzett konfirmatív faktorelemzés eredményei azt mutatták, hogy a háromdimenziós modell illeszkedése nem megfelelő $\left(c^{2}(630)=2306,169 ; p<0,001 ; \mathrm{CFI}=0,524 ;\right.$ TLI = 0,491 RMSEA =0,086), ezért exploratív faktoranalízist végeztünk a további lépésben (maximum likelihood becsléssel, varimax forgatással). Az elemzést három lépésben hajtottuk végre: először bevontuk az összes változót, második lépésben a nem jól illeszkedő tételeket azonosítottuk, harmadik lépésben a faktorelemzés alapján a más alskálához tartozó tételeket ellenőriztük és helyeztük át.

A tételek a Bartlett-teszt $(p<0,001)$ és a KMO-érték $(0,948)$ alapján alkalmasnak bizonyultak a faktorelemzésre. A 2. táblázatban az első lépésben kapott eredmények szerepelnek, ami többnyire megegyezik az elméleti, az eredeti angol nyelvú kérdőív struktúrájával. A hazai változatban, az eredetihez hasonlóan, három faktor különült el: (1) Erőfeszítés alapú kontroll, (2) Extraverzió (Surgency), (3) Negatív érzelmi viszonyulás, és csak három item került más faktorba az eredetileg meghatározottal szemben (a táblázatban X-szel jelöltek jelzik az eredeti helyet). Az összes tétel bevonásával a három faktor a teljes variancia 59\%-át magyarázza. Mindegyik tétel kommunalitása megfelel a kritériumoknak $(>0,25)$, azonban volt három olyan item, amelyekról a számottevő kereszttöltések miatt nem lehetett eldönteni, hogy melyik faktorhoz tartoznak. 
Az első lépésben létrejött faktorok belső megbízhatósága (Cronbach-a) megfelelőnek bizonyult (Erőfeszítés alapú kontroll: 0,75; Extraverzió (Surgency): 0,76; Negatív érzelmi viszonyulás: 0,70), azonban úgy gondoltuk, a rosszul múködő itemek ellenőrzésével ez tovább javítható.

2. táblázat. A CBQ VS-H faktorelemzésének eredménye (faktorstruktúra, faktorsúlyok)

\begin{tabular}{|c|c|c|c|}
\hline Tételek & $\begin{array}{l}\text { 1. faktor } \\
\text { Erófeszítés } \\
\text { alapú } \\
\text { kontroll }\end{array}$ & $\begin{array}{l}\text { 2. faktor } \\
\text { Extraverzió } \\
\text { (Surgency) }\end{array}$ & $\begin{array}{l}\text { 3. faktor } \\
\text { Negatív } \\
\text { érzelmi } \\
\text { viszonyulás }\end{array}$ \\
\hline $\begin{array}{l}\text { 3. Rajzolás és színezés közben nagyon } \\
\text { koncentrál. }\end{array}$ & 0,45 & & \\
\hline $\begin{array}{l}\text { 6. Kirándulásokra készülve megtervezi, } \\
\text { hogy mire lesz szüksége. }\end{array}$ & 0,46 & & \\
\hline 9. Szereti, ha énekelnek neki. & 0,45 & & \\
\hline 12. Észreveszi, ha a szülei új ruhát viselnek. & 0,70 & & \\
\hline $\begin{array}{l}\text { 15. Hosszú ideig leköti és elmélyülten } \\
\text { játszik a kirakós, és építős játékokkal. }\end{array}$ & 0,39 & & \\
\hline 18. Jól követi az utasításokat. & 0,52 & & \\
\hline 21. Szereti a mondókák ritmusát. & 0,56 & & \\
\hline $\begin{array}{l}\text { 24. Hamar észreveszi az új változásokat } \\
\text { a lakásban. }\end{array}$ & 0,61 & & \\
\hline $\begin{array}{l}\text { 27. Néha teljesen belemerül egy } \\
\text { képeskönyvbe, és sokáig nézegeti azt. }\end{array}$ & 0,37 & & \\
\hline 28. Szereti a durva és verekedős játékokat. & $-0,39$ & $x$ & \\
\hline $\begin{array}{l}\text { 30. Lassan és óvatosan közelít meg olyan } \\
\text { helyeket, amikről azt mondták neki, hogy } \\
\text { veszélyesek. }\end{array}$ & 0,46 & $-0,38$ & \\
\hline 33. Szereti, amikor ringatják és hintáztatják. & 0,57 & & \\
\hline $\begin{array}{l}\text { 35. Szomorú lesz, amikor a számára kedves } \\
\text { rokonok vagy barátok készülődnek } \\
\text { hazamenni egy-egy látogatás alkalmával. }\end{array}$ & 0,42 & & $x$ \\
\hline $\begin{array}{l}\text { 36. Szóvá teszi, ha a szülei megjelenésén } \\
\text { valamilyen változás történt. }\end{array}$ & 0,67 & & \\
\hline $\begin{array}{l}\text { 1. Mindig nagyon siet, amikor egyik helyről } \\
\text { a másikra megy. }\end{array}$ & & 0,38 & \\
\hline $\begin{array}{l}\text { 4. Szeret magasról lecsúszni vagy más } \\
\text { kalandokban részt venni. }\end{array}$ & & 0,63 & \\
\hline 7. Gyakran belevág új helyzetekbe. & & 0,68 & \\
\hline 10. Könnyen kijön szinte mindenkivel. & 0,35 & 0,39 & \\
\hline
\end{tabular}




\begin{tabular}{|c|c|c|c|}
\hline Tételek & $\begin{array}{l}\text { 1. faktor } \\
\text { Erófeszítés } \\
\text { alapú } \\
\text { kontroll }\end{array}$ & $\begin{array}{l}\text { 2. faktor } \\
\text { Extraverzió } \\
\text { (Surgency) }\end{array}$ & $\begin{array}{l}\text { 3. faktor } \\
\text { Negatív } \\
\text { érzelmi } \\
\text { viszonyulás }\end{array}$ \\
\hline $\begin{array}{l}\text { 13R. Jobban kedveli a csendes } \\
\text { foglalkozásokat, mint a mozgásos } \\
\text { tevékenységeket. }\end{array}$ & & 0,59 & \\
\hline $\begin{array}{l}\text { 16. Hintázás közben szereti, ha gyorsan } \\
\text { és magasra lökik. }\end{array}$ & & 0,46 & \\
\hline $\begin{array}{l}\text { 19R. Sokáig tart, amíg megszokja az új } \\
\text { helyzeteket. }\end{array}$ & & 0,54 & $-0,39$ \\
\hline $\begin{array}{l}\text { 22R. Néha még az olyan emberek } \\
\text { társaságában is félénk, akiket már régóta } \\
\text { ismer. }\end{array}$ & & 0,65 & \\
\hline $\begin{array}{l}\text { 23. Ha szomorú, nagyon nehéz } \\
\text { megvigasztalni. }\end{array}$ & & $-0,37$ & $X$ \\
\hline 25. Még este is tele van energiával. & & 0,39 & \\
\hline $\begin{array}{l}\text { 31R. Lassan és ráérősen dönti el, } \\
\text { hogy mit tegyen. }\end{array}$ & & 0,59 & \\
\hline $\begin{array}{l}\text { 34R. Néha félénken elhúzódik azoktól, } \\
\text { akiket nem ismer eléggé. }\end{array}$ & & 0,75 & \\
\hline $\begin{array}{l}\text { 2. Meglehetősen frusztrálttá válik, } \\
\text { ha megakadályozzák valamiben. }\end{array}$ & & & 0,51 \\
\hline $\begin{array}{l}\text { 5. Már egy kis karcolástól és ütéstől is } \\
\text { eléggé elkeseredik. }\end{array}$ & & & 0,56 \\
\hline $\begin{array}{l}\text { 8. Hajlamos elszomorodni, ha valami nem } \\
\text { úgy történik a családban, ahogy } \\
\text { eltervezték. }\end{array}$ & & & 0,58 \\
\hline 11. Fél a betöróktól vagy a „mumustól”. & & & 0,31 \\
\hline $\begin{array}{l}\text { 14. Ha mérges valami miatt, hajlamos tíz } \\
\text { percig vagy annál is tovább bosszankodni. }\end{array}$ & & & 0,61 \\
\hline $\begin{array}{l}\text { 17. Elkeseredik, ha nem sikerül teljesítenie } \\
\text { valamilyen feladatot. }\end{array}$ & & & 0,63 \\
\hline 20R. Megfázás esetén alig panaszkodik. & & & 0,39 \\
\hline \multicolumn{4}{|l|}{ 26R. Nem fél a sötéttől. } \\
\hline $\begin{array}{l}\text { 29R. Nem keseredik el a kisebb } \\
\text { karcolásoktól, ütésektől. }\end{array}$ & & & 0,52 \\
\hline $\begin{array}{l}\text { 32. Mérges lesz, ha nem találja azt, amivel } \\
\text { játszani akar. }\end{array}$ & & & 0,61 \\
\hline
\end{tabular}

Megjegyzés: A 0,30 alatti faktorsúly-értékek nem szerepelnek a táblázatban. X: a tétel eredeti helye. R: fordított item. 
A második lépésben azonosítottuk a nem jól múködő tételeket. Az Extraverzió faktorból kivettük a 10. (Könnyen kijön szinte mindenkivel) és 28. (Szereti a durva és verekedős játékokat) tételt, a Negatív viszonyulás faktorból a 26R (Nem fél a sötéttől), a 11. (Fél a betörőktôl vagy a „mumustól”) és a 35. (Szomorú lesz, amikor a számára kedves rokonok vagy barátok készülödnek hazamenni egyegy látogatás alkalmával) tételt.

A harmadik lépésben azon tételek helyét módosítottuk, amelyeket a faktoranalízis modellje máshová sorolt. Így az Erőfeszítés alapú kontrollfaktorba áttettük a 28. tétel fordított változatát és a 35. tételt, az Extraverzió faktorba pedig a 23. tételt (Ha szomorú, nagyon nehéz megvigasztalni) tettük át megfordított értékekkel. A módosítások alapján minden faktor esetében valamennyivel emelkedtek a megbízhatósági értékek (Cronbach-a): Erőfeszítés alapú kontroll: 0,76; Extraverzió: 0,78; Negatív viszonyulás: 0,74; amelyek így kissé magasabbak is lettek az angol változathoz képest (1. fentebb). Ugyanakkor az elemzések azt mutatták, hogy a tételek, illetve a skálák további módosítása nem növelné jelentősen a Cronbach- $a$ értékeket, emiatt az így kialakult faktorokkal dolgoztunk tovább.

Ellenőriztük a skálák belső megbízhatóságát a kitöltők személye (anya vagy apa) alapján is (3. táblázat). A méróeszköz mindhárom faktora megfelelő belső konzisztencia mutatókkal rendelkezik mindkét alminta esetében, tehát a kitöltő személye (anya vagy apa) szempontjából nincs különbség a mérőeszköz megbízhatóságában. Ez megegyezik az angol változat során kapott eredménnyel, ahol szintén megbízhatóan múködött mind az anya, mind az apa által kitöltött mérőeszköz (Putnam \& Rothbart, 2006).

3. táblázat. A CBQ VS-H alapstatisztikája és belsó megbízhatósági mutatói a szülői almintákon

\begin{tabular}{|l|c|c|c|}
\hline \multirow{2}{*}{ CBQ VS-H faktorai } & \multirow{2}{*}{$\begin{array}{c}\text { Átlag (SD) } \\
\text { teljes minta }\end{array}$} & \multicolumn{2}{c|}{ Cronbach- $\boldsymbol{\alpha}$} \\
\cline { 3 - 4 } & & Anyák $(\boldsymbol{n}=\mathbf{1 7 6})$ & Apák $(\boldsymbol{n}=\mathbf{2 5})$ \\
\hline Erőfeszítés alapú kontroll & $3,93(0,46)$ & 0,78 & 0,74 \\
\hline Extraverzió (Surgency) & $3,54(0,56)$ & 0,78 & 0,79 \\
\hline Negatív érzelmi viszonyulás & $2,93(0,56)$ & 0,74 & 0,75 \\
\hline
\end{tabular}




\subsection{Konvergens és divergens validitás}

A CBQ VS-H faktorait összevetettük a végrehajtó funkciókkal, amit a vizsgálatban a gyerekekkel felvett mérőeszközökkel, a HTKS $(\mathrm{M}=31,33$; $\mathrm{SD}=$ 7,55; terjedelem: $0-40)$ és a Nappal-Éjszaka $(\mathrm{M}=27,73$; $\mathrm{SD}=6,87$; terjedelem: 0-32) tesztekkel mértünk. A 4. táblázatban a CBQ VS-H faktorai és a végrehajtó funkciókat vizsgáló méróeszközök közötti Pearson-féle korrelációs együtthatók szerepelnek. Egy esetben találtunk szignifikáns kapcsolatot: a negatív érzelmi viszonyulás mutatott negatív előjelú, igen gyenge összefüggést a Nappal-Éjszaka Teszt összpontszámával. Ez azt jelenti, hogy a negatív érzelmi viszonyulásra való fokozott hajlam együtt jár a NappalÉjszaka Teszten elért alacsonyabb teljesítménnyel.

4. táblázat. A CBQ VS-H faktorainak összefüggései

a HTKS és a Nappal-Éjszaka tesztekkel

\begin{tabular}{|l|c|c|}
\hline \multicolumn{1}{|c|}{ Faktor } & $\begin{array}{c}\text { HTKS } \\
\text { összpontszám }\end{array}$ & $\begin{array}{c}\text { Nappal-Éjszaka Teszt } \\
\text { összpontszám }\end{array}$ \\
\hline Erőfeszítés alapú kontroll & 0,12 & 0,02 \\
\hline Extraverzió (Surgency) & 0,09 & 0,04 \\
\hline Negatív érzelmi viszonyulás & $-0,10$ & $-0,16^{*}$ \\
\hline
\end{tabular}

Megjegyzés: Pearson-féle korrelációs együtthatók. * p<0,05

\subsection{A CBQ VS-H dimenzióinak összefüggése háttérváltozókkal}

Többszörös lineáris regresszióelemzéssel vizsgáltuk meg, hogy a kérdőívet kitöltők demográfiai háttere mennyiben befolyásolja az eredményeket, vagyis a temperamentum három vizsgált faktorát. Az 5. táblázatban a dichotomizált szociodemográfiai háttérváltozók befolyásoló szerepét összesítettük: a kitöltő szülő $(1=$ anya, $2=$ apa $)$, a szülő életkora $(1=40$ év alatti, $2=$ 40 év feletti), a szülő iskolai végzettsége ( 1 = legfeljebb középfokú, 2 = felsőfokú) és családi állapota ( 1 = házasságban, kapcsolatban, 2 = nincs kapcsolatban). Függő változónak minden esetben a CBQ VS-H kérdőív által vizsgált faktorokat (erőfeszítés alapú kontroll, extraverzió, negatív érzelmi viszonyulás) választottuk.

Eredményeink szerint a kérdőívet kitöltő szülőnek sem a személye (anya vagy apa), sem az életkora, sem az iskolai végzettsége, sem pedig családi állapota nem mutatott szignifikáns összefüggést a gyermekek temperamentumjellemzőivel. 
5. táblázat. A háttérváltozók kapcsolata a CBQ VS-H faktoraival (lineáris regresszió elemzés)

\begin{tabular}{|c|c|c|c|c|c|c|c|c|c|}
\hline \multirow[t]{2}{*}{ Háttérváltozók } & \multicolumn{3}{|c|}{$\begin{array}{l}\text { Erófeszítés alapú } \\
\text { kontroll }\end{array}$} & \multicolumn{3}{|c|}{$\begin{array}{l}\text { Extraverzió } \\
\text { (Surgency) }\end{array}$} & \multicolumn{3}{|c|}{$\begin{array}{l}\text { Negatív érzelmi } \\
\text { viszonyulás }\end{array}$} \\
\hline & $B$ & $\beta$ & $p$ & $B$ & $\beta$ & $p$ & $B$ & $\beta$ & $p$ \\
\hline $\begin{array}{l}\text { Szülő } \\
(1=\text { anya, } 2=\text { apa })\end{array}$ & $-0,10$ & $-0,07$ & 0,362 & 009 & 0,05 & 0,478 & 0,23 & 0,13 & 0,076 \\
\hline $\begin{array}{l}\text { Életkor } \\
(1=40 \text { év alatt, } \\
2=40 \text { év felett) }\end{array}$ & 0,13 & 0,11 & 0,155 & 0,14 & 0,09 & 0,216 & 0,08 & 0,05 & 0,479 \\
\hline $\begin{array}{l}\text { Iskolai végzettség } \\
(1=\text { legfeljebb } \\
\text { középfokú, } \\
2=\text { felsőfokú) }\end{array}$ & 0,02 & 0,02 & 0,762 & 0,08 & 0,07 & 0,350 & $-0,03$ & $-0,03$ & 0,728 \\
\hline $\begin{array}{l}\text { Családi állapot } \\
(1=\text { házasságban, } \\
\text { kapcsolatban, } \\
2=\text { nincs } \\
\text { kapcsolatban })\end{array}$ & $-0,04$ & $-0,03$ & 0,734 & $-0,08$ & $-0,04$ & 0,634 & $-0,06$ & $-0,03$ & 0,706 \\
\hline $\mathrm{R}^{2} / \Delta \mathrm{R}^{2}$ & \multicolumn{3}{|c|}{$0,02 /-0,01$} & \multicolumn{3}{|c|}{$0,05 / 0,03$} & \multicolumn{3}{|c|}{$0,03 / 0,01$} \\
\hline
\end{tabular}

\section{Megbeszélés}

Tanulmányunkban a legrövidebb Gyermeki Viselkedés Kérdőív (Putnam \& Rothbart, 2006) magyar nyelvre adaptált változatának (CBQ VS-H) pszichometriai elemzését mutattuk be. A mérőeszközre a fejlesztés és a korábbi használat során alapvetően háromdimenziós temperamentummutatóként utalnak (Putnam \& Rothbart, 2006). A konfirmatív faktoranalízis eredményeként kiderült, hogy a magyar nyelvre adaptált változatban nem jó az adatok illeszkedése az elméleti modellre. A CBQ VS kialakításakor a szerzők a rövid változatból (CBQ S) konfirmatív faktoranalízis révén hozták létre ezt a változatot, de nem ellenőrizték a gyakorlatban a múködését (Putnam \& Rothbart, 2006), így az általunk kapott eredmény kevéssé meglepó. Ugyanakkor a miénkhez hasonló eredményeket kapott Allan, Lonigan és Wilson (2013) is, akik kutatásukban a CBQ VS pszichometriai mutatóit ellenőrizték, és a konfirmatív faktorelemzésük kapcsán szintén rossz illeszkedési mutatókat találtak.

Az exploratív faktorelemzéssel kapott eredményeink azonban azt mutatták, hogy három tétel kivételével és három tétel más faktorba helyezésével megbízhatóan múködő, jó belső megbízhatósággal rendelkező mérőeszköz alakítható ki, ami hasonlóan az eredetihez, háromfaktoros struktúrát mutat. 
A CBQ VS-H mérőeszköz mindkét általunk vizsgált részmintán (anya, apa mint kitöltő) jó megbízhatósági mutatókkal rendelkezik, ami megegyezik a nemzetközi eredményekkel (Putnam \& Rothbart, 2006).

A végrehajtó funkciókat vizsgáló mérőeszközökkel (HTKS, NappalÉjszaka Teszt) való korrelációs elemzések eredményei azt mutatták, hogy általában nincs összefüggés, csupán az egyik dimenzió, a negatív érzelmi viszonyulás mutat szignifikáns, negatív előjelú, igen gyenge összefüggést a Nappal-Éjszaka Teszt összpontszámával. A nemzetközi vizsgálatok ellentétes eredményekről számolnak be a végrehajtó funkciók és az erőfeszítés alapú kontroll mint temperamentumvonás kapcsolatáról (Liew, 2012; Zhou és mtsai, 2012). Eredményeink illeszkednek azokhoz a kutatásokhoz, amelyekben gyenge összefüggést mutattak ki e két komponens között, és egymástól független tényezőnek tekintik a végrehajtó funkciókat és erőfeszítés alapú kontrollt (Carlson \& Moses, 2001; Davis és mtsai, 2002; Rothbart és mtsai, 2003). Ennek hátterében állhat a két konstruktum mérési módszereinek különbözősége (szülői kérdőív vs. a gyerek megfigyelése), de figyelembe vehetjük a Friedman és Miyake (2017) által kialakított egységességdiverzitás modell szempontjait is, amely alapján az önszabályozásban vannak egységes folyamatok (mint pl. gátlás, figyelem), de a kontextuális különbségek miatt számos különböző kimenetele lehet ennek a folyamatnak, aminek empirikus bizonyítása éppen ezért nehézségekbe ütközik (l. még Miyake, Friedman, Emerson, Witzki, \& Howerter, 2000). Mindezeket figyelembe véve, megállapítható, hogy a CBQ VS-H konvergens és divergens validitásának alátámasztásához érdemes más mérőeszközöket is bevonni a további kutatásokba (pl. végrehajtó funkciók kérdőíves vizsgálata, más temperamentumkérdóívek bevonása).

A vizsgált szociodemográfiai háttérváltozók (kitöltő személye, szülő életkora, iskolai végzettsége, családi állapota) egyike sem befolyásolja a CBQ VS-H temperamentumdimenzióit. Ez arra utal, hogy a gyermekek vizsgált temperamentumdimenziói valószínúleg nem érzékenyek a kitöltő személy háttérjellemzői alapján jelentkező torzításokra.

Kutatásunk több korláttal bír, ide tartozik például a minta relatíve kicsi elemszáma, valamint a kényelmi mintavétel. A jövőben érdemes lenne nagyobb elemszámmal, reprezentatív mintán megismételni a kutatást, és az időbeli stabilitást is ellenőrizni, ami ebből a kutatásból kimaradt. Habár a skála hétfokúról ötfokúra való csökkentése nem jelzett problémát a kérdőív múködésében és pszichometriai mutatóiban, amennyiben a hazai és nemzetközi eredmények összehasonlítása fontos, érdemes az eredeti hétfokú skálával felvenni a méróeszközt. Mindezek mellett az eredményeink azt mutatják, hogy a jól értelmezhetó kijelentések és megbízhatósági mutatók miatt érdemes használni a CBQ VS-H-t a temperamentumkutatásokban. Ugyanakkor a későbbiekben további területek és mérőeszközök bevonása szüksé- 
ges, amelyekkel még inkább kimutatható a Gyermeki Viselkedés Kérdőív által lefedett temperamentumdimenziók összefüggéseinek és kapcsolódásainak struktúrája. Mindazonáltal fontosnak tartjuk, hogy ne csak a szülők, hanem a pedagógusok is töltsék ki az adott gyerekről a kérdőívet, ami által még pontosabb képet kaphatunk a gyerekek temperamentumáról és viselkedéséről.

\section{Irodalom}

Allan, N.P., Lonigan, C.J., \& Wilson, S.B. (2013). Psychometric evaluation of the Children's Behavior Questionnaire - Very Short Form in preschool children using parent and teacher report. Early Childhood Research Quarterly, 28, 302-313.

Blair, C. (2002). School readiness: Integrating cognition and emotion in a neurobiological conceptualization of child functioning at school entry. American Psychologist, 57, 111-127.

Blair, C., \& Razza, R.P. (2007). Relating effortful control, executive function, and false belief understanding to emerging math and literacy ability in kindergarten. Child Development, 78, 647-663.

Capaldi, D.M., \& Rothbart, M. K. (1992). Development and validation of an Early Adolescent Temperament Measure. Journal of Early Adolescence, 12, 153-173.

Carlson, S.M., \& Moses, L.J. (2001). Individual differences in inhibitory control and children's theory of mind. Child Development, 72, 1032-1053.

D. Molnár, É. (2017). Erőfeszítés alapú kontroll és végrehajtó funkciók az önszabályozásban. Magyar Pszichológiai Szemle, 72(4), 509-523.

D. Molnár, É., \& Kovács, D. (2018). A HTKS és Day-Night tesztek hazai alkalmazása óvodások körében. Kézirat.

Davis, E.P., Bruce, J., \& Gunnar, M.R. (2002). The anterior attention network: Associations with temperament and neuro endocrine activity in 6-year-old children. Developmental Psychobiology, 40, 43-56.

Derryberry, D., \& Rothbart, M.K. (1988). Arousal, affect, and attention as components of temperament. Journal of Personality and Social Psychology, 55, 958-966.

Digman, J.M. (1990). Personality structure: Emergence of the five-factor model. Annual Review of Psychology, 41, 417-440.

Duncan, G.J., Dowsett, C.J., Claessens, A., Magnuson, K., Huston, A.C., Klebanov, P., et al. (2007). School readiness and later achievement. Developmental Psychology, 43, 1428-1446.

Eisenberg, N., Valiente, C., Fabes, R.A., Smith, C.L., Reiser, M., Shepard, S.A., et al. (2003). The relations of effortful control and ego control to children's resiliency and social functioning. Developmental Psychology, 39, 761-776.

Gerstadt, C.L., Hong, Y.J., \& Diamond, A. (1994). The relationship between cognition and action: Performance of children 3.5-7 years old on a Stroop-like day-night test. Cognition, 53, 129-153.

Gilliam, W.S., \& Shahar, G. (2006). Prekindergarten expulsion and suspension: Rates and predictors in one state. Infants and Young Children, 19, 228-245.

Guthrie, I.K., Eisenberg, N., Fabes, R.A., Murphy, B.C., Holmgren, R., Mazsk, P., et al. (1997). The relations of regulation and emotionality to children's situational empathy-related responding. Motivation and Emotion, 21, 87-108.

Howse, R.B., Calkins, S.D., Anastopoulos, A.D., Keane, S.P., \& Shelton, T.L. (2003). Regulatory contributors to children's kindergarten achievement. Early Education and Development, 14(1), 101-119. 
Liew, J. (2012). Effortful control, executive functions, and education: Bringing self-regulatory and social-emotional competencies to the table. Child Development Perspectives, 6(2), 105-111.

Martin, R.P., Drew, D., Gaddis, L.R., \& Moseley, M. (1988). Prediction of elementary school achievement from pre-school temperament: Three studies. School Psychology Review, 17, 125-137.

Miyake, A., Friedman, N.P., Emerson, M.J., Witzki, A.H., \& Howerter, A. (2000). The unity and diversity of executive functions and their contributions to complex "frontal lobe" tasks: A latent variable analysis. Cognitive Psychology, 41, 49-100.

Normandeau, S., \& Guay, F. (1998). Preschool behavior and first grade school achievement: The meditational role of cognitive self-control. Journal of Educational Psychology, 90, 111-121.

Ponitz, C.C., McClelland, M.M., Jewkes, A.M., Connor, C.M., Farris, C.L., \& Morrison, F.J. (2008). Touch your toes! Developing a direct measure of behavioral regulation in early childhood. Early Childhood Research Quarterly, 23, 141-158.

Ponitz, C.C., McClelland, M.M., Matthews J.S., \& Morrison, F.J. (2009). A structured observation of behavioral self-regulation and its contribution to kindergarten outcomes. Developmental Psychology, 45(3), 605-619.

Putnam, S.P., Gartstein, M.A., \& Rothbart, M.K. (2006). Measurement of fine-grained aspects of toddler temperament: The Early Childhood Behavior Questionnaire. Infant Behavior and Development, 29(3), 386-401.

Putnam, S.P., \& Rothbart, M.K. (2006). Development of short and very short forms of the Children's Behavior Questionnaire. Journal of Personality Assessment, 87, 102-112.

Raver, C.C. (2004). Placing emotional self-regulation in sociocultural and socioeconomic contexts. Child Development, 75(2), 346-353.

Rothbart, M.K. (1981). Measurement of temperament in infancy. Child Development, 52, 569-578.

Rothbart, M.K., \& Ahadi, S.A. (1994). Temperament and the development of personality. Journal of Abnormal Psychology, 103, 55-66.

Rothbart, M.K., Ahadi, S.A., \& Hershey, K.L. (1994). Temperament and social behavior in childhood. Merrill-Palmer Quarterly, 40(1), 21-39.

Rothbart, M.K., Ahadi, S.A., Hersey, K.L., \& Fisher, P. (2001). Investigations of temperament at three to seven years: The Children's Behavior Questionnaire. Child Development, 72, 1394-1408.

Rothbart, M.K., \& Bates, J.E. (2006). Temperament. In N. Eisenberg, W. Damon, \& R. M. Lerner (Eds.), Handbook of child psychology: Vol. 3. Social, emotional, and personality development (6th ed., 99-166). Hoboken, NJ: Wiley

Rothbart, M.K., \& Derryberry, D. (1981). Development of individual differences in temperament. In M.E. Lamb, \& A. Brown (Eds.), Advances in developmental psychology (Vol. 1, pp. 37-86). Hillsdale, NJ: Erlbaum

Rothbart, M.K., Ellis, P., Rueda, R., \& Posner, M. (2003). Developing mechanisms of temperamental effortful control. Journal of Personality, 71(6), 1113-1143.

Rothbart, M.K., \& Jones, L.B. (1998). Temperament, self-regulation, and education. School Psychology Review, 27, 479-491.

Simonds, J., \& Rothbart, M.K. (2004). The temperament in middle childhood questionnaire (TMCQ): A computerized self-report measure of temperament for ages 7-10. Poster session presented at the occasional temperament conference. University of Georgia, Athens, October 28-31, 2004. Letöltve: 2019.01.10-én: https:// research.bowdoin.edu/rothbarttemperament-questionnaires/files/2016/09/TMCQ_Poster_Oct04.pdf 
Valiente, C., Lemery-Chalfant, K., \& Castro, K.S. (2007). Children's effortful control and academic competence. Mediation through school liking. Merrill-Palmer Quarterly, 53, 1-25.

Zhou, Q., Chen, S.H. \& Main, A. (2012). Commonalities and Differences in the Research on Children's Effortful Control and Executive Function: A Call for an Integrated Model of Self-Regulation. Child Development Perspectives, 6(2), 112-121.

\section{Köszönetnyilvánítás}

D. Molnár Éva a tanulmány megírása alatt Bolyai János Kutatási Ösztöndíjban részesült.

\section{Szerzói munkamegosztás}

A kutatás szakmai és operatív vezetőjeként az elméleti háttér, az adatok statisztikai elemzése, és a kézirat szövegezése D. Molnár Éva munkája. Az elméleti háttér kidolgozásában, a mérőeszköz fordításában való segédkezés, valamint az adatok értelmezése és a kézirat végső szövegezése Kovács Dénes munkájához tartozik.

\section{Nyilatkozat érdekütközésról}

A szerzők ezúton kijelentik, hogy esetükben nem állnak fenn érdekütközések. 


\section{Függelék: Gyermeki Viselkedés Kérdôív (CBQ VS-H)}

Kedves Szülő! A továbbiakban néhány kijelentést fog olvasni, amelyek a gyermekek reakcióit fogalmazzák meg különböző helyzetekben. Arra vagyunk kíváncsiak, hogy az Ön gyermeke hogyan reagál ezekben a helyzetekben. Természetesen, nincsenek „,helyes" reakciók, hiszen a gyerekek nagyon különböző módokon reagálnak, amik megismerése révén jobban megérthetjük viselkedésüket. Kérjük, olvassa el a kijelentéseket, és mindegyik kapcsán ítélje meg, hogy mennyire igaz az adott kijelentés a gyermekére az elmúlt hat hónap tapasztalata alapján! Minden kijelentés mellett karikázza be a gyermekére leginkább jellemző értékelés számát!

Ha nem tud válaszolni egy adott kijelentés kapcsán, mert nem látta még gyermekét abban a helyzetben, jelölje meg az NA - nem alkalmazható - kategóriát! Figyeljen rá, hogy minden kijelentés esetében karikázzon be egy számot vagy a nem alkalmazható kategóriát!

\begin{tabular}{|c|l|c|c|c|c|c|c|}
\hline & \multicolumn{1}{|c|}{ A gyermekem... } & $\begin{array}{c}\text { Több- } \\
\text { nyire } \\
\text { sosem } \\
\text { igaz rá }\end{array}$ & $\begin{array}{c}\text { Általá- } \\
\text { ban } \\
\text { nem } \\
\text { igaz rá }\end{array}$ & $\begin{array}{c}\text { Néha } \\
\text { igaz rá, } \\
\text { néha } \\
\text { nem }\end{array}$ & $\begin{array}{c}\text { Általá- } \\
\text { ban } \\
\text { igaz rá }\end{array}$ & $\begin{array}{c}\text { Több- } \\
\text { nyire } \\
\text { mindig } \\
\text { igaz rá }\end{array}$ & $\begin{array}{c}\text { Nem } \\
\text { alkal- } \\
\text { mazható }\end{array}$ \\
\hline 1. & $\begin{array}{l}\text { Mindig nagyon siet, } \\
\text { amikor egyik helyról } \\
\text { a másikra megy. }\end{array}$ & 1 & 2 & 3 & 4 & 5 & NA \\
\hline 2. & $\begin{array}{l}\text { Meglehetósen } \\
\text { frusztrálttá válik, } \\
\text { ha megakadályozzák } \\
\text { valamiben. }\end{array}$ & 1 & 2 & 3 & 4 & 5 & NA \\
\hline 3. & $\begin{array}{l}\text { Rajzolás és színezés } \\
\text { közben nagyon } \\
\text { koncentrál. }\end{array}$ & 1 & 2 & 3 & 4 & 5 & NA \\
\hline 4. & $\begin{array}{l}\text { Szeret magasról } \\
\text { lecsúszni vagy más } \\
\text { kalandokban részt } \\
\text { venni. }\end{array}$ & 1 & 2 & 3 & 4 & 5 & NA \\
\hline 5. & $\begin{array}{l}\text { Már egy kis } \\
\text { karcolástól és ütéstól } \\
\text { is eléggé elkeseredik. }\end{array}$ & 1 & 2 & 3 & 4 & 5 & NA \\
\hline 6. & $\begin{array}{l}\text { Kirándulásokra } \\
\text { készülve megtervezi, } \\
\text { hogy mire lesz } \\
\text { szüksége. }\end{array}$ & 1 & 2 & 3 & 4 & 5 & NA \\
\hline
\end{tabular}




\begin{tabular}{|c|c|c|c|c|c|c|c|}
\hline & A gyermekem... & $\begin{array}{l}\text { Több- } \\
\text { nyire } \\
\text { sosem } \\
\text { igaz rá }\end{array}$ & $\begin{array}{l}\text { Általá- } \\
\text { ban } \\
\text { nem } \\
\text { igaz rá }\end{array}$ & $\begin{array}{l}\text { Néha } \\
\text { igaz rá, } \\
\text { néha } \\
\text { nem }\end{array}$ & $\begin{array}{l}\text { Általá- } \\
\text { ban } \\
\text { igaz rá }\end{array}$ & $\begin{array}{l}\text { Több- } \\
\text { nyire } \\
\text { mindig } \\
\text { igaz rá }\end{array}$ & $\begin{array}{c}\text { Nem } \\
\text { alkal- } \\
\text { mazható }\end{array}$ \\
\hline 7. & $\begin{array}{l}\text { Gyakran belevág } \\
\text { új helyzetekbe. }\end{array}$ & 1 & 2 & 3 & 4 & 5 & NA \\
\hline 8. & $\begin{array}{l}\text { Hajlamos } \\
\text { elszomorodni, } \\
\text { ha valami nem úgy } \\
\text { történik a családban, } \\
\text { ahogy eltervezték. }\end{array}$ & 1 & 2 & 3 & 4 & 5 & NA \\
\hline 9. & $\begin{array}{l}\text { Szereti, ha énekelnek } \\
\text { neki. }\end{array}$ & & 2 & 3 & 4 & 5 & NA \\
\hline 10. & $\begin{array}{l}\text { Könnyen kijön szinte } \\
\text { mindenkivel. }\end{array}$ & & 2 & 3 & 4 & 5 & NA \\
\hline 11. & $\begin{array}{l}\text { Fél a betörőktől vagy } \\
\text { a "mumustól". }\end{array}$ & & 2 & 3 & 4 & 5 & NA \\
\hline 12. & $\begin{array}{l}\text { Észreveszi, } \\
\text { ha a szülei új ruhát } \\
\text { viselnek. }\end{array}$ & & 2 & 3 & 4 & 5 & NA \\
\hline 13. & $\begin{array}{l}\text { Jobban kedveli } \\
\text { a csendes } \\
\text { foglalkozásokat, } \\
\text { mint a mozgásos } \\
\text { tevékenységeket. }\end{array}$ & & 2 & 3 & 4 & 5 & NA \\
\hline 14 & $\begin{array}{l}\text { Ha mérges valami } \\
\text { miatt, hajlamos } \\
\text { tíz percig vagy } \\
\text { annál is tovább } \\
\text { bosszankodni. }\end{array}$ & & 2 & 3 & 4 & 5 & NA \\
\hline 15. & $\begin{array}{l}\text { Hosszú ideig leköti } \\
\text { és elmélyülten } \\
\text { játszik a kirakós, } \\
\text { és építős játékokkal. }\end{array}$ & & 2 & 3 & 4 & 5 & NA \\
\hline 16. & $\begin{array}{l}\text { Hintázás közben } \\
\text { szereti, ha gyorsan } \\
\text { és magasra lökik. }\end{array}$ & & 2 & 3 & 4 & 5 & NA \\
\hline 17. & $\begin{array}{l}\text { Elkeseredik, ha nem } \\
\text { sikerül teljesítenie } \\
\text { valamilyen feladatot. }\end{array}$ & & 2 & 3 & 4 & 5 & NA \\
\hline 18. & $\begin{array}{l}\text { Jól követi } \\
\text { az utasításokat. }\end{array}$ & & 2 & 3 & 4 & 5 & NA \\
\hline
\end{tabular}




\begin{tabular}{|c|c|c|c|c|c|c|c|}
\hline & A gyermekem... & $\begin{array}{l}\text { Több- } \\
\text { nyire } \\
\text { sosem } \\
\text { igaz rá }\end{array}$ & $\begin{array}{l}\text { Általá- } \\
\text { ban } \\
\text { nem } \\
\text { igaz rá }\end{array}$ & $\begin{array}{l}\text { Néha } \\
\text { igaz rá, } \\
\text { néha } \\
\text { nem }\end{array}$ & $\begin{array}{l}\text { Általá- } \\
\text { ban } \\
\text { igaz rá }\end{array}$ & $\begin{array}{l}\text { Több- } \\
\text { nyire } \\
\text { mindig } \\
\text { igaz rá }\end{array}$ & $\begin{array}{c}\text { Nem } \\
\text { alkal- } \\
\text { mazható }\end{array}$ \\
\hline 19. & $\begin{array}{l}\text { Sokáig tart, } \\
\text { amíg megszokja } \\
\text { az új helyzeteket. }\end{array}$ & & 2 & 3 & 4 & 5 & NA \\
\hline 20. & $\begin{array}{l}\text { Megfázás esetén alig } \\
\text { panaszkodik. }\end{array}$ & & 2 & 3 & 4 & 5 & NA \\
\hline 21. & $\begin{array}{l}\text { Szereti a mondókák } \\
\text { ritmusát. }\end{array}$ & & 2 & 3 & 4 & 5 & NA \\
\hline 22. & $\begin{array}{l}\text { Néha még } \\
\text { az olyan emberek } \\
\text { társaságában is } \\
\text { félénk, akiket már } \\
\text { régóta ismer. }\end{array}$ & & 2 & 3 & 4 & 5 & NA \\
\hline 23. & $\begin{array}{l}\text { Ha szomorú, nagyon } \\
\text { nehéz } \\
\text { megvigasztalni. }\end{array}$ & & 2 & 3 & 4 & 5 & NA \\
\hline 24. & $\begin{array}{l}\text { Hamar észreveszi } \\
\text { az új változásokat } \\
\text { a lakásban. }\end{array}$ & & 2 & 3 & 4 & 5 & NA \\
\hline 25. & $\begin{array}{l}\text { Még este is tele van } \\
\text { energiával. }\end{array}$ & & 2 & 3 & 4 & 5 & NA \\
\hline 26. & Nem fél a sötéttől. & & 2 & 3 & 4 & 5 & NA \\
\hline 27. & $\begin{array}{l}\text { Néha teljesen } \\
\text { belemerül egy } \\
\text { képeskönyvbe, } \\
\text { és sokáig nézegeti } \\
\text { azt. }\end{array}$ & & 2 & 3 & 4 & 5 & NA \\
\hline 28. & $\begin{array}{l}\text { Szereti a durva és } \\
\text { verekedős játékokat. }\end{array}$ & & 2 & 3 & 4 & 5 & NA \\
\hline 29. & $\begin{array}{l}\text { Nem keseredik el } \\
\text { a kisebb } \\
\text { karcolásoktól, } \\
\text { ütésektől. }\end{array}$ & & 2 & 3 & 4 & 5 & NA \\
\hline 30. & $\begin{array}{l}\text { Lassan és óvatosan } \\
\text { közelít meg olyan } \\
\text { helyeket, amikról } \\
\text { azt mondták neki, } \\
\text { hogy veszélyesek. }\end{array}$ & & 2 & 3 & 4 & 5 & NA \\
\hline
\end{tabular}




\begin{tabular}{|l|l|c|c|c|c|c|c|}
\hline & \multicolumn{1}{|c|}{ A gyermekem... } & $\begin{array}{c}\text { Több- } \\
\text { nyire } \\
\text { sosem } \\
\text { igaz rá }\end{array}$ & $\begin{array}{c}\text { Általá- } \\
\text { ban } \\
\text { nem } \\
\text { igaz rá }\end{array}$ & $\begin{array}{c}\text { Néha } \\
\text { igaz rá, } \\
\text { néha } \\
\text { nem }\end{array}$ & $\begin{array}{c}\text { Általá- } \\
\text { ban } \\
\text { igaz rá }\end{array}$ & $\begin{array}{c}\text { Több- } \\
\text { nyire } \\
\text { mindig } \\
\text { igaz rá }\end{array}$ & $\begin{array}{c}\text { Nem } \\
\text { alkal- } \\
\text { mazható }\end{array}$ \\
\hline 31. & $\begin{array}{l}\text { Lassan és ráérósen } \\
\text { dönti el, hogy mit } \\
\text { tegyen. }\end{array}$ & 2 & 3 & 4 & 5 & NA \\
\hline 32. & $\begin{array}{l}\text { Mérges lesz, ha nem } \\
\text { találja azt, amivel } \\
\text { játszani akar. }\end{array}$ & 2 & 3 & 4 & 5 & NA \\
\hline 33. & $\begin{array}{l}\text { Szereti, amikor } \\
\text { ringatják és } \\
\text { hintáztatják. }\end{array}$ & 2 & 3 & 4 & 5 & NA \\
\hline 34. & $\begin{array}{l}\text { Néha félénken } \\
\text { elhúzódik azoktól, } \\
\text { akiket nem ismer } \\
\text { eléggé. }\end{array}$ & 2 & 3 & 4 & 5 & NA \\
\hline 35. & $\begin{array}{l}\text { Szomorú lesz, } \\
\text { amikor a számára } \\
\text { kedves rokonok } \\
\text { vagy barátok } \\
\text { készülődnek } \\
\text { hazamenni egy-egy } \\
\text { látogatás alkalmával. }\end{array}$ & $\begin{array}{l}\text { Szóvá teszi, ha a } \\
\text { szülei megjelenésén } \\
\text { valamilyen változás } \\
\text { történt. }\end{array}$ & & 3 & 4 & 5 & NA \\
\hline 36. & & 2 & 5 & NA & \\
\hline
\end{tabular}

\section{Skálaképzési útmutató:}

A skálaképzés a fordított (R-betúvel jelölt) tételek megfordítása után, az egyes skálákhoz tartozó tételek összeadásával és átlagolásával történik. A nem alkalmazható kategóriát 0 értékkel kódoljuk.

Extraverzió skála: 1., 4., 7., 13R., 16., 19R., 22R., 23R., 25., 31R. és 34R. tétel.

Erőfeszítés alapú kontroll skála: 3., 6., 9., 12., 15., 18., 21., 24., 27., 28R., 30., 33., 35. és 36. tétel.

Negatív érzelmi viszonyulás skála: 2., 5., 8., 14., 17., 20R., 23., 29R. és 32. tétel.

Az eredeti kérdőívhez képest kihagyott itemek: 10., 11. és 26R. tétel. 


\section{Hungarian version of the Children's Behavior Questionnaire very short form (CBQ VS)

\author{
D. MOLNÁR, ÉVA - KOVÁCS, DÉNES
}

Theoretical background: One of the most widely accepted and used measurement in temperament research is Children's Behavior Questionnaire (CBQ), which was designed to caregiver report of 3- to 8-year-old children's temperament. There has been no available Hungarian version so far. Aim: The aim of our study is to present the adaptation of Hungarian version of the Children's Behavior Questionnaire very short form (CBQ VS) and to present these psychometric properties. Method: The sample were 5-7 years old children $(N=201)$ and their parents $(N=201)$ from three Hungarian cities. The CBQ VS-H questionnaire was completed by parents (mother $N=176$, father $N=25$ ). Besides the CBQ VS-H we measured children's executive functions by HTKS and Day-Night tests. Results: Explorative factor analysis provided, similar to the original version, three main factors in adapted version with good internal consistency values: Effortful control (Cronbach's alpha: .76), Surgency (Cronbach's alpha: .78), Negative Affect (Cronbach's alpha: .74). Dimensions of temperament were independent of sociodemographic characteristics (person - mother or father, age, education). Conclusions: Based on our results, the Hungarian version of Children's Behavior Questionnaire very short form (CBQ VS) is a reliable and valid measurement for assessing three dimensions of children's temperament.

Keywords: temperament, children's behaviour, self-regulation, CBQ, psychometric properties

A cikk a Creative Commons Attribution 4.0 International License (https:/ / creativecommons.org/ licenses/by/4.0/) feltételei szerint publikált Open Access közlemény, melynek szellemében a cikk bármilyen médiumban szabadon felhasználható, megosztható és újraközölhető, feltéve, hogy az eredeti szerzó és a közlés helye, illetve a CC License linkje és az esetlegesen végrehajtott módosítások feltüntetésre kerülnek. (SID_1) 